\title{
Development Of Lectora Inspire Based Learning Media For Human Body
} Anatomy

\author{
Aref Vai $^{1}$, Slamet $^{2}$,Agus Prima Aspa ${ }^{3}$, Muhammad Imam Rahmatullah ${ }^{4}$, Fitri Agung Nanda ${ }^{5}$ \\ ${ }^{123}$ Fakultas Keguruan Ilmu Pendidikan, Universitas Riau, Indonesia \\ ${ }^{45}$ Universitas Negeri Yogyakarta, Indonesia. \\ Email:aref.vai@lecturer.unri.ac.id ${ }^{1}$, slamet@ lecturer.unri.ac.id ${ }^{2}$, agus.prima@ lecturer.unri.ac.id ${ }^{3}$, \\ muhammadimamrahmatullah@gmail.com ${ }^{4}$, fitriagungnanda16@gmail.com ${ }^{5}$
}

Menerima: 20 October 2020; Revisi: 05 November 2020; Diterima: 09 November 2020

https://doi.org/10.24036/MensSana.050220.09

\begin{abstract}
Nowadays that show the existence of learning innovations using online devices require learning innovations. The purpose of this research is to develop learning media for human body anatomy based on Lectora Inspire. The method used in research is research and development (Research \& Development). Lectora Inspire is an application that is used to develop instructional media products. In this study, the researchers analyzed that learning human body anatomy based on Lectora inspire was still not widely used. Therefore, research on this learning media is quite urgent to do. Researchers provide a different point of view regarding Lectora's inspire-based learning media. In doing the validation, the researchers tested the material, media, and learning validation by experts in their fields. Data were analyzed using quantitative descriptive analysis techniques that were expressed in the distribution of scores and a predetermined category rating scale. The sample used 12 involved students who took part in learning. Based on the results of the evaluation in the field of material received an average score of 4.19 and categorized as good. Evaluation in the media sector has an average score of 4.31 and is categorized as good, and students' responses in the small group average score of 4.26 are categorized as good. From the results of this study, it can be concluded that the Lectora Inspire application is very effective in using learning media, especially human anatomy because it is supported by features that can facilitate the learning process.
\end{abstract}

\section{Keywords: Anatomy, Learning Media, Lectora Inspire, Application, Learning of Inovasi}

\section{INTRODUCTION}

The development of science and technology increasingly encourages renewal efforts in the use of technological results in the teaching and learning process. Advances in technology have also made many changes in various aspects of life (Kurniawan, Mujasam, Yusuf, \& Widyaningsih, 2019). Teachers are required to be able to use the tools that can be provided by schools, and these tools are by the developments and demands of the times.

The teacher can at least use simple tools, but it is a must for a teacher to achieve the expected teaching goals. Besides being able to use the available tools, teachers are also required to be able to develop the available tools, teachers are also required to be able to develop skills in making teaching media that will be used in the media is not yet available.
Wibawa, (2017) through his research, argues that learning media is expected to help teachers achieve learning goals. Teachers' ability to develop learning media is also influenced by the habits of Generation $\mathrm{Z}$ who are very close to technology. This requires a teacher to be able to increase creativity in learning to keep up with advances in technology. E-leaning learning in detail has begun to be implemented so that students and parents can also be involved in the learning process( Dhika2019).

According to (Sardirman, 2009) the use of instructional media can clarify the presentation of the material so as not to verbalize According to (Linda, Erviyenni, Noer, Oktavianti, \& Sellyna, 2016) learning media makes it easier for students to digest learning. Research on online learning was conducted by (O'Byrne, Patry, \& Carnegie, 2008). The result of this research is 
that online learning can be accessed easily by students, especially when they are learning independently.

There are many kinds of learning media. According to (Cecep \& Bambang, 2011) learning media can be grouped into four groups, namely (1) print technology media, (2) audio-visual technology media, (3) computer-based technology media, (4) combined print and computer technology. Of the four types of media, the media will be maximized when using a combination of print technology and computers because it contains several forms of computercontrolled media.

Anatomy is the science of body structure in humans. In the anatomy of the human body, it will be seen that humans have a lot of elements that make up one human body. These elements consist of the digestive system, respiratory system, reproductive system, muscular system, sensory system, nervous system.

This research discusses all the organs of the human body. Luklukaningsih \& Zuyina, (2014)Knowledge of the anatomy of the human body is very important. To be able to know the normal process and bad conditions if there is a disease attacking the anatomy of the body. So that you can anticipate in the form of prevention for your health. That's why learning the anatomy of the human body has become an important material that must be understood from now on for students and society.

Often, the learning materials available in anatomy textbooks are not sufficient enough to help students understand body anatomy. This requires learning innovation. In line with what (Davis, Bates, Ellis, \& Roberts, 2014) said, the anatomy learning curriculum has experienced a lot of development and modification of learning. To be more effective, learning anatomy requires short and long-term teaching by (Losco, Grant, Armson, Meyer, \& Walker, 2017) with interesting anatomy learning strategies (Mathiowetz, Yu, \& Quake-Rapp, 2016) Also, a coherent learning experience for students is considered so that the learning function runs well (Guy, Byrne, \& Dobos, 2018).

Today, the rapid development of technology has an influence in various fields, including education. Education by utilizing technology will facilitate the learning process (Kurniawan et al., 2019). The technology currently used is presented in the form of instructional media to facilitate the teaching- learning process as well as increase the attractiveness of students during the learning process, this also happens in learning Pencak silat.

Various efforts are made to create an interactive learning process. This can be seen from various studies that have produced IT-based learning models such as that conducted by regarding Android-based Human Anatomy Learning Media. The research resulted in an ITbased learning model. The software used in the process of making this learning model is Android Studio (IDE).

Research conducted by (Rochmatika(2015), is one of them. Research with the title Interactive Learning Media Lectora Inspire as a Learning Innovation is a form of research that produces a learning model using an application that is easy to use. A new offer comes from a Lectora Inspire application that offers its users the ease of operating the application. The use of this application does not require a person who is truly an IT expert.

The Lectora Inspire application is an effective program in making learning media. This application is an electronic learning development (e-learning) software which is relatively easy because it does not require an understanding of a sophisticated programming language. The same thing was also expressed by (Zuhri \& Rizaleni) who said that the Lectora Inspire application is generally easy to use because the diction used is not too complicated and quite effective when used.

This is because the Lectora Inspire application has an interface that is familiar to those of us who already know or master Microsoft Office. Also, according to Lectora Inspire said this learning media has proven its validity in improving students' learning abilities. Another advantage of the Lectora Inspire application is that it has features that can help users to create various multimedia (images, animation, audio, video). Lectora Inspire also has complete features, starting from entering images, audio, video, and educational games

From some of the studies and theories that have been described, it can be said that IT-based learning media is needed in the process of learning the anatomy of the human body. Lectora Inspire has never been done. Given the convenience that the application offers, it is necessary that the application is also used in the 
human anatomy learning process to increase the variety of learning models that can be created easily to be more effective.

Van Sint Jan et al., (2003) argued that anatomy learning through learning media would make learning more interesting. Lectora inspires can be the answer to more interesting learning developments. Because Lectora inspires can combine various videos, images, and screen capture (R Hikmi et al, 2020).

Mathiowetz (2016) can also be done effectively as long as there is seriousness from the students themselves. Research conducted by Ulfatuzzahra (2020) concluded that the Lectora Inspire application is very effective in the learning process. An effective learning process will certainly increase the learning interest of students (Apriniya, P \& Aisyah, M, 2019). Technology-based research has been conducted by Irmawati et al (2017) that the use of android greatly facilitates the learning process.

Research on learning models that will be applied to the anatomy of the human body within the scope of Riau University. With the convenience that the application offers, it is hoped that it will be able to create an attractive audio-visual based human anatomy learning media so that it can improve the learning process by using the Lectora Inspire application.

\section{METHODS}

The method used in this study uses a research development approach (Research \& Development). According to Sukmadinata in Titting, Hidayah, \& Pramono (2016) defines research and development as a research approach to produce new products or improve existing products. educational research as a development goal is to produce products based on field test findings, then if there are weaknesses in the product being developed, revisions will be made (Akbarini, N. R et al, 2018). research subjects numbered 12 people.

The research was carried out from June to September 2020. The steps in this study included (1) Competency Standards, (2) Potentials and Problems, (3) Needs Analysis, (4) Design and Implementation, (5) Products, (6) ) Expert Validation, (7) Product Revision, (8) Trial Use, (9) Product Revision, (10) Mass Production. The feasibility of the developed media was carried out using qualitative descriptive statistical tests on the results of the feasibility test data.
Due diligence by media experts, material experts, and users. The data obtained were used to carry out the process of developing learning media products in the form of quantitative data and qualitative data. The analysis technique used is the quantitative descriptive analysis technique with the help of the calculation of the t-test spss.

\section{RESULTS and DISCUSSION Results}

Based on the results of the data that has been obtained through the validation test, the learning indicators are categorized as good with a mean score of 4.25. Then the material indicators are categorized as good, the average score is 4.13. The assessment criteria for the learning indicators are at a percentage of $85 \%$ in the good category, and the material indicators are at $80 \%$ in the good category.

The following shows the material quality assessment data obtained from the assessment results in table 1:

Table 1. Material Expert Validation

\begin{tabular}{ccc}
\hline Rated aspect & $\begin{array}{c}\text { Average } \\
\text { Score }\end{array}$ & Criteria \\
\hline $\begin{array}{c}\text { Learning } \\
\text { Aspects }\end{array}$ & 4.25 & Good \\
$\begin{array}{c}\text { Content / } \\
\text { Material aspects } \\
\text { Average }\end{array}$ & 4.13 & Good \\
\hline
\end{tabular}

The next process after the material has been validated is continued with the creation of learning media that will be used in elaboration lectures. The next process is then carried out the editing process and converted to the Lectora Inspire application, then tested for validation by media experts. After going through the revision, the evaluation was carried out, so the average rating was 4.30 with a good category display indicator. Then the category indicators of programming aspects are good at an average of 4.33.

Based on the data obtained from 21 statement items on the display indicators relating to the excellence of the resulting media, a percentage of $73.70 \%$ is obtained and categorized as good and programming indicators related to the superiority of the resulting media, $80 \%$ data is very good category The quality of learning media products results from the validation of media experts through the process of distributing questionnaires. The following 
shows the media quality assessment data obtained from the assessment results in table 2:

Table 2.Validation of Outline Science Learning Media

\begin{tabular}{ccc}
\hline Rated aspect & $\begin{array}{c}\text { Average } \\
\text { Score }\end{array}$ & Criteria \\
\hline $\begin{array}{c}\text { Aspects of } \\
\text { Media }\end{array}$ & 4,30 & Good \\
$\begin{array}{c}\text { Programming } \\
\text { Aspects }\end{array}$ & 4,33 & Good \\
Average & $\mathbf{4 , 3 1}$ & Good \\
\hline
\end{tabular}

The development of learning media in essay science lecture material with Lectora inspire-based audiovisual media has gone through a validation testing process carried out with the aim of whether the human body anatomy learning media in essay science lectures with Lectora inspire-based audiovisual media is feasible or not suitable for use in the learning process.

It is necessary to know that the development of this product has not yet reached the perfect stage because the results of the trial are only limited to validating the material and appearance and have not been tested in small groups and large groups, therefore there is a need for further development.

\section{Discussion}

This research is to develop learning media for human body anatomy using Lectora Inspire. This is because there is still a small amount of human anatomy learning material using Lectora Inspire. the results of the study reveal if this media is good to use. With these results, it is hoped that Lectora Inspire can be used in Physical Education learning, it does not rule out the possibility of other courses besides anatomy.

Even though it has good results, this study has a drawback, namely the limited sample used, it is hoped that for further research it can be in the medium of Lectora Inspire to be able to increase the research sample. The results of this study indicate that students and educators need technology-based media to support the learning process.

The results of research regarding the development of instructional technology media are following several previous research results. inline with it. The Industrial Revolution 4.0 makes all aspects connected to technology (Oktavianingtyas, Salama, Fatahillah, Monalisa,
\& Setiawan, 2018). Likewise with the educational aspect. If the focus is on innovation, technological advances are very beneficial for an educator (Mudinillah, 2019).

Web-based applications are currently being integrated into the educational curriculum (Zargaran, Turki, Bhaskar, Spiers, \& Zargaran, 2020). Currently, the government is also focusing on continuing to build learning media infrastructure (Akbarini, Murtini, \& Rahmanto, 2018).

The learning process that is now being carried out during the Covid 19 pandemic requires educators to learn a lot in terms of preparing the media used in learning. The phenomenon that is happening now is that many teachers have used YouTube, Zoom, Google Meet, and so on as a medium in the learning process.

As we all know, the inability of an educator to utilize learning media will have an impact on boredom in the process that is not following the learning styles of students causing learning to run less effectively. On the other hand, increasing the ability of students is influenced by their learning style (Eagleton, 2015). According to Burner (Agam, Rahayu, \& Achmad Rifai, 2015), he said there are three levels of learning mode, namely direct experience (inactive), pictorial experience (iconic), and stark experience (symbolic).

Several studies have been carried out that using media in the learning process will be able to increase students' interest in learning so that learning runs effectively because the media has several advantages that can be used to increase interest and the effectiveness of learning. According to (Arsyad \& Azhar, 2007) media is a component of learning resources or physical vehicles that contain instructional material in the student environment that can stimulate student learning.

The development of Lectora inspire-based media in the human body anatomy material is designed to be used as a learning media for elaboration science lecture materials, where the process goes through a development research process that starts from the planning, making, and assessment/evaluation process.

This learning media also involves an interactive process between educators and students (Thwin, 2017). Effective strategies are also used to make learning more interesting 
(Singh, Bharatha, Sa, Adams, \& Majumder, 2019). Lectora inspires in the learning process also has great potential to help improve student learning achievement (Nursidik \& Suri, 2018).

Products developed using one of the interactive learning applications, namely the Lectora Inspire application. The Lectora inspire application is an application that can be used by various groups (Saputro, Masturi, \& Supriyadi, 2020). Products that have been developed will be validated by experts. Arisman, (2019) revealed that learning using media can improve the volleyball smash skills carried out by students. This is proven by the learning outcomes given after using the media are better than before using the media in learning volleyball.

Various efforts are made to create an interactive learning process. This can be seen from various studies that have resulted in ITbased learning models such as that conducted by (Vai, Ramadi, Juita, \& Sulaastio, 2019) regarding the development of multimedia-based learning media for high school level pencak silat.

The media using a smartphone is a good way to support success in volleyball learning, media in the form of smartphones is considered very effective considering that today smartphones are one of the things that are always considered by everyone. It is further stated that the use of smartphone media is one of the good tricks that can be applied in learning volleyball service material Physical Education (Bakhri et al., 2020).

The research resulted in an IT-based learning model. The software used in the process of making this learning model is Adobe Flash CS. In addition, research on other it-based pencak silat learning models with the title of developing Macromedia flash 8 based pencak silat learning media for junior high schools has also been carried out (Valentino \& Ihsan, 2018), This research resulted in a product in the form of a $\mathrm{CD}$ of Interactive Multimedia learning media using the Macromedia Flash 8 application in the subjects of physical education, sports and health, grade VIII grade martial arts material.

Research conducted by ( Pradana, 2012). learning food test biology using Adobe Flash Professional CS5 can be used in learning biology food test practices. Then the research conducted by (Setiani, 2015) states that interactive learning media with the Adobe Flash CS5 application is for material to appreciate short story texts.

Researchers chose the Adobe Flash CS5 application because it allows the creating of interactive learning media consisting of complete features so that the media developed can actively engage students' senses of sight and hearing so that the process of material absorption is maximized. Furthermore, the research conducted by (Putranto, 2012) in which the results of his research designed and made animal classification educational games as a biology learning medium with macadamia flash CS 5 .

The research was conducted by (Rochmatika(2015), 2015) where the purpose of this study was to produce an interesting and interactive multimedia-based Origami learning media application product, to determine the feasibility of multimedia-based Origami learning media application.

In research (Palelupu \& Cholik, 2014) developed adobe flash CS5-based learning media in technical drawing training through stages of development procedures and through expert validation of learning media, to find out whether the application of developed learning media can improve student learning outcomes, for knowing student responses to learning media that have been developed and to find out obstacles in the development of learning media.

The implications of research based on theoretical studies and empirical studies will have an impact on student learning because learning can have a positive impact on students and for others, as student motivation to participate in learning and teacher motivation in creating, developing, and using learning media.

\section{CONCLUSION}

Technological advances in various fields have had a significant impact on the continuity of learning in schools and colleges. Changes in learning patterns from only face-to-face learning have increased with online learning. In terms of time and place, online learning is quite effective because it is not bound by time and space. The demands of the times that require educators to be proficient in using technology, require every educator to come up with innovative ideas that can facilitate access to learners' learning.

Thus the learning objectives at the school and college level will be achieved. The anatomy of the human body is the knowledge that can 
now be accessed in various references. However, there are still not many Lectora inspire-based learning media developed. Therefore, lectora inspire-based anatomy learning media need to be investigated further.

The development of Lectora Inspire-based Anatomy learning media has gone through a validation testing process carried out by validating the material and media appearance and has not conducted a large group field test process. For this reason, this research still needs to be continued.

Based on the data obtained, the display indicators related to the excellence of the resulting media obtained a percentage of $73.70 \%$, and in the good category and programming indicators related to the superiority of the resulting media obtained $80 \%$ data in the very good category. From the results of this study, it can be concluded that the learning media based on Lectora Inspire is suitable for use in the learning process.

\section{REFERENCES}

Agam, G. A., Rahayu, S., \& Achmad Rifai. (2015). Journal of Physical Education and Sports, 4(1), 28-36.

Akbarini, N. R., Murtini, W., \& Rahmanto, A. N. (2018). The effect of Lectora inspire-based interactive learning media in vocational high school. Jurnal Pendidikan Vokasi, $8(1), 78$.

https://doi.org/10.21831/jpv.v8i1.17970

AP_Harry Dhika_ICALC. (n.d.).

Arisman. (2019). Peningkatan hasil belajar smash bolavoli melalui pembelajaran berbasis media. Jurnal Menssana, 4(1), 6675.

Arsyad, \& Azhar. (2007). Media Pembelajaran. Jakarta. Jakarta: Raja Grafindo Persada.

Bakhri, R. S., Nurjaman, D., Listiandi, A. D., Festiawan, R., Ginanjar, D. A., Kesehatan, F. I., \& Soedirman, U. J. (2020). Pemanfaatan Aplikasi Smartphone : Meningkatkan Keterampilan Service Atas Bola Voli, 96-105.

Cecep, K., \& Bambang. (2011). Media
Pembelajaran Manual dan Digital. Bogor: Ghalia Indonesia.

Davis, C. R., Bates, A. S., Ellis, H., \& Roberts, A. M. (2014). Human anatomy: Let the students tell us how to teach. Anatomical Sciences Education, 7(4), 262-272. https://doi.org/10.1002/ase.1424

Eagleton, S. (2015). An exploration of the factors that contribute to learning satisfaction of first-year anatomy and physiology students. Advances in Physiology Education, 39(1), 158-166. https://doi.org/10.1152/advan.00040.2014

Guy, R., Byrne, B., \& Dobos, M. (2018). Optional anatomy and physiology elearning resources: Student access, learning approaches, and academic outcomes. Advances in Physiology Education, 42(1), 43-49. https://doi.org/10.1152/advan.00007.2017

Kurniawan, R. B., Mujasam, M., Yusuf, I., \& Widyaningsih, S. W. (2019). Development of physics learning media based on Lectora Inspire Software on the elasticity and Hooke's law material in senior high school. Journal of Physics: Conference Series, 1157(3). https://doi.org/10.1088/17426596/1157/3/032022

Linda, R., Erviyenni, Noer, A. M., Oktavianti, N. A., \& Sellyna, N. (2016). Development of Lectora Inspire as Interactive Multimedia Chemistry Learning in Senior High School. Jurnal Pendidikan Kimia, 8(3), 188-196.

Losco, C. D., Grant, W. D., Armson, A., Meyer, A. J., \& Walker, B. F. (2017). Effective methods of teaching and learning in anatomy as a basic science: A BEME systematic review: BEME guide no. 44 . Medical Teacher, 39(3), 234-243. https://doi.org/10.1080/0142159X.2016.12 71944

Luklukaningsih, \& Zuyina. (2014). Anatomi Fisiologi dan Fisioterapi. Yogyakarta: Nuha Medika.

Mathiowetz, V., Yu, C. H., \& Quake-Rapp, C. (2016). Comparison of a gross anatomy 
laboratory to online anatomy software for teaching anatomy. Anatomical Sciences Education, 9(1), 52-59. https://doi.org/10.1002/ase.1528

Mudinillah, A. (2019). The Development of Interactive Multimedia Using Lectora Inspire Application in Arabic Language Learning. Jurnal Iqra' : Kajian Ilmu Pendidikan, 4(2), 285-300. https://doi.org/10.25217/ji.v4i2.570

Nursidik, H., \& Suri, I. R. A. (2018). Media Pembelajaran Interaktif Berbantu Software Lectora inspire. Desimal: Jurnal Matematika, 1(2), 237. https://doi.org/10.24042/djm.v1i2.2583

O’Byrne, P. J., Patry, A., \& Carnegie, J. A. (2008). The development of interactive online learning tools for the study of Anatomy. Medical Teacher, 30(8). https://doi.org/10.1080/0142159080223281 8

Oktavianingtyas, E., Salama, F. S., Fatahillah, A., Monalisa, L. A., \& Setiawan, T. B. (2018). Development 3D Animated Story as Interactive Learning Media with Lectora Inspire and Plotagon on Direct and Inverse Proportion Subject. Journal of Physics: Conference Series, 1108(1). https://doi.org/10.1088/17426596/1108/1/012111

Palelupu, D. N., \& Cholik, M. (2014). Pengembangan Media Pembelajaran Berbasis Adobe Flash CS5 Pada Mata Diklat Gambar Teknik Di Kelas X TPM SMK Krian 1 Sidoarjo. Jurnal Pendidikan Teknik Mesin, 3(2), 10-19.

Putranto, A. (2012). Pengembangan game edukasi klasifikasi hewan menggunakan.

Radyan Pradana. (n.d.). Pengembangan Media Pembelajaran Biologi Uji Makanan Menggunakan Adobe Flash Professional Cs5.

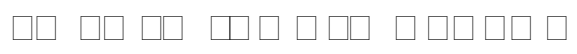

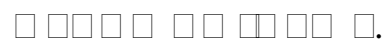

Rochmatika(2015). (2015). Aplikasi Media Pembelajaran Origami Berbasis Flash
Menggunakan Adobe Flash Cs5.

Universitas Negeri Yogyakarta, 1-166.

Saputro, N. V., Masturi, \& Supriyadi. (2020). The effectiveness of instructional media based on lectora inspire towards student's achievement. Journal of Physics: Conference Series, 1567(2), 4-10. https://doi.org/10.1088/1742$6596 / 1567 / 2 / 022063$

Sardirman. (2009). Media Pendidikan: Pengertian, Pengembangan dan Pemanfaatannya. Jakarta: PT Raja Grafindo Persada.

Setiani, R. (2015). Pengembangan Media Pembelajaran Mengapresiasi Teks Cerita Pendek Berbasis Adobe Flash CS5 Untuk Kelas XI SMA. Skripsi Tidak Terpublikasi. Universitas Negeri .... Retrieved from https://core.ac.uk/download/pdf/33514099. pdf

Singh, K., Bharatha, A., Sa, B., Adams, O. P., \& Majumder, M. A. A. (2019). Teaching anatomy using an active and engaging learning strategy. BMC Medical Education, 19(1), 1-8. https://doi.org/10.1186/s12909019-1590-2

Thwin, E. P. A. (2017). Practical Tips for Effective and Efficient Anatomy Teaching. Medical Science Educator, 27(2), 363-370. https://doi.org/10.1007/s40670-017-0390-8

Vai, A., Ramadi, Juita, A., \& Sulaastio, A. (2019). The Media Development of Pencak Silat Learning Multimedia Based at SMA/MA, 4(2), 359-366. https://doi.org/10.2991/acpes-19.2019.40

Valentino, R., \& Ihsan, N. (2018). Pengembangan Media Pembelajaran Pencak Silat Berbasis Macromedia Flash 8 Untuk Sekolah Menengah Pertama, 1(1), 23-24.

Wibawa, S. C. (2017). the Design and Implementation of an Educational Multimedia Interactive Operation System Using Lectora Inspire. Elinvo (Electronics, Informatics, and Vocational Education), 
2(1), 74-79.

https://doi.org/10.21831/elinvo.v2i1.16633

Zargaran, A., Turki, M. A., Bhaskar, J., Spiers,

H. V. M., \& Zargaran, D. (2020). <p>The

Role of Technology in Anatomy Teaching:

Striking the Right Balance $</ \mathrm{p}>$. Advances

in Medical Education and Practice, Volume

$11,259-266$.

https://doi.org/10.2147/amep.s240150 